\title{
Research on Teaching Reform of Testing Technology Course Based on Innovation and Entrepreneurship Training
}

\author{
Wei Zhang \\ Automation and Electrical Engineering Institute \\ Linyi University \\ Linyi, Shandong, China \\ Email:zhwei369@163.com
}

\begin{abstract}
The innovation and entrepreneurship training is the main goal of the current talent cultivation in China and points out the direction for the development of higher education. The article introduced the current development situation of domestic and international innovation and entrepreneurship education, and introduced the role of the detection technology curriculum, from the construction of a team of teachers with innovation and entrepreneurship, the reform of curriculum content, the reform of teaching methods, and the reform of experimental teaching models. The use of Internet technology and actively guide students to participate in various levels of discipline teams and college students innovative and entrepreneurial projects in several aspects of the analysis of curriculum reform, pointed out the significance of curriculum reform, and provides a theoretical basis for the curriculum reform of detection technology.
\end{abstract}

Keywords: innovation and entrepreneurship; curriculum reform; detection technology;

\section{INTRODUCTION}

In the world higher education reform movement at the turn of the century, the developed countries all regard the cultivation of innovative and entrepreneurial talents as one of the main objectives of the reform. The United States is particularly typical. Entrepreneurship and innovation have become the main theme of the current world economic development. Since the 1990s, American universities have continued to innovate in education, and have gradually developed a unique model for fostering innovative entrepreneurial talents. The key to the strong growth and dynamism of the U.S. economy since the 1990s is the innovative spirit of the entire society and the continuous entrepreneurial activities of millions of small businesses. The emergence of an entrepreneurial society may be an important turning point in history. In the history of the United States, entrepreneurship has added vitality to the U.S. economy and has supported sustained and strong economic development in the United States in recent decades. Entrepreneurship and innovation are the foundation for the economic prosperity of the United States. Entrepreneurship has become the most important strategic advantage of the United States. China's innovation and entrepreneurship education has experienced three phases: spontaneous exploration, multiple exploration, and comprehensive promotion. Taking the "Opinions on Vigorously Promoting Innovation and Entrepreneurial Education and University Students' Self-starting Work" of the Ministry of Education as a symbol, it has entered the stage of comprehensive promotion under the guidance of the education administrative department.

\section{Inspection Technology Overview}

"Testing Technology" is a professional core course in professional series platform courses such as automation and electrical information. It is an applied and practical course. It is closely related to the actual engineering and is the industrial automation production technology work. The indispensable important link, it is widely used in transportation, electricity, metallurgy, chemical industry, building materials and other fields of automated equipment and production automation process. The research and application of detection technology not only has important theoretical significance, but also conforms to the strategy for the development of science and technology in China for a long period of time now and in the future, and it closely integrates with the actual situation of the national economy and has important implications for the promotion of technological progress and traditional industrial technology.

Through the curriculum reform, students are proficient in various kinds of detection technology knowledge, and can be skillfully applied to practical projects, combined with specific engineering practice projects, improve students' application ability, practical ability, and improve students' spirit of innovation and entrepreneurship ability.

\section{CONTENTS OF RESEARCH ON REFORMS OF TESTING TECHNOLOGY COURSES}

\section{A. Building a Teaching Staff with Innovation and Entrepreneurial Ability}

Teachers play a crucial role in innovation and entrepreneurship education. Without a certain number and quality of innovative and entrepreneurial teachers, it is impossible to cultivate students with innovative and entrepreneurial qualities. At present, teachers in colleges and universities generally have the idea of innovation and entrepreneurship is not strong, teaching methods are outdated, the overall level of innovation and entrepreneurship teachers is not high, and the quality of innovation and entrepreneurship education is hindered. Current school teachers mainly focus on teaching basic theory. They mainly use duck-filled teaching methods and lack the exploration of students' interests, innovative thinking and the cultivation of innovative abilities. At the 
same time, teachers lack innovation and training. Due to the heavy teaching tasks of teachers, participation in scientific research projects, and the limited time and energy for innovative training, the result is that most teachers of teachers do not have strong entrepreneurial awareness and insufficient innovation capabilities. Therefore, in order to solve this problem, we organize teachers to participate in innovation and entrepreneurship education and training, strengthen teachers' ability to innovate and innovate, and at the same time organize teachers to deepen enterprises and companies, understand the business management of enterprises, understand the investment or entrepreneurship of enterprises, and be able to relate theory with practice in teaching. , To teach students the innovative entrepreneurial experience learned in the enterprise to students, we must let teachers firmly establish the concept of innovation and entrepreneurship education, the cultivation of student innovation, entrepreneurial ability as an important task of teaching. In addition, we have stepped up cooperation with industry and hired entrepreneurs, entrepreneurial successes, people with entrepreneurial frustration, technical experts, company management personnel, and various types of experts and scholars (including scientific research, economic management, and law). Part-time entrepreneurial tutors, to achieve efficient integration of social and school resources, to establish a high-quality innovative and entrepreneurial education teachers team with a complete range of levels, combined with part-time job. This part of the staff is relatively easy to grasp the purpose, significance and operation of self-employment, because they have macroeconomic management practices, are familiar with the process of business operations, so you can teach students through the entrepreneurial practice courses in entrepreneurship to avoid detours.

\section{B. Reform of Teaching Content}

The teaching content of the traditional detection technology courses mainly teaches the working principle of the various sensors used in the detection technology and the measurement conversion circuit. It emphasizes teaching in the classroom theory and focuses on "learning" and "skills". In this mode, the The students' ability to work independently, discover problems, and analyze problem-solving abilities, innovative spirits, and entrepreneurial abilities have led to a lack of student independence and teamwork, innovation, and entrepreneurial ability. Constructing teaching content that adapts to international standards and adapts to social development, and focuses on student inquiry activities. The content of curriculum teaching should keep pace with the times, closely follow the development frontier of the major and disciplines, closely integrate the needs of social and economic development, strengthen the links and cross-cutting of related professional teaching content, and timely convert the latest teaching and research achievements into teaching content. The teaching curriculum system focuses on systematicness. Starting from training objectives, it focuses on cultivating students' comprehensive knowledge, practical ability, and innovation and entrepreneurial quality. It also increases the selectivity and flexibility of the curriculum, and encourages students to acquire a solid professional foundation through related professional development. The broad professional vision enables students to develop and improve their innovative and entrepreneurial skills so that they can achieve a more comprehensive and coordinated development.

\section{Teaching Method Reform}

The teaching methods of the "Testing Technology" course have been adjusted accordingly. At this stage, there are mainly three types of teaching modes: (1) Traditional teaching modes combined with modern teaching methods. For example, "Classroom Teaching" adopted by Xi'an University of Technology + Practical teaching + networked teaching, careful selection of theoretical content and design practice projects, and remote tutoring of students through open networks. The teaching method is suitable for the teaching of undergraduate colleges with strong initiative and solid theoretical basis. (2) Task-driven teaching mode. (3) Project-guided teaching mode. The latter two teaching modes are student-centered and competence-based. Both belong to the action-oriented teaching method. Task-driven teaching method means that teachers design teaching content into one or more specific tasks, strive to be task-driven, take an instance as a guide, and then ask questions to guide students to think, so that students can master teaching content by learning and doing, to achieve teaching The goal is to develop students' ability to analyze problems and solve problems. This mode is conducive to the teaching of a single course, but it uses mature cases and tasks, and it cannot mobilize the students' initiative to explore problems. If there is no good form of organization, it is difficult to cultivate students' teamwork spirit. The project-guided teaching model is an instructional activity for teachers and students through joint implementation of a complete project work. Hand over a relatively independent project product to the student himself. Information collection, project design, project implementation and final evaluation are all the responsibility of the students themselves. Through the implementation of the project, students understand and grasp the basic requirements of the entire process and each link. In principle, there should be a product that can be seen after the project ends. It is somewhat different from task-driven teaching methods. This method is suitable for students with product design experience, certain professional knowledge and strong learning initiative. If the teacher cannot design the teaching content and assessment method of the related project well, the teaching method will be in a form. In order to better realize the cultivation of students' innovative spirit and entrepreneurial ability, we propose a project-guided task-driven teaching model and a flipping classroom teaching method.

The project-guided task-driven teaching model does not simply superimpose the two concepts, but adopts different teaching methods for different training objectives and different knowledge content in the curriculum system 
through educational objects, educational purposes, and other aspects. Its teaching mode combines the advantages of traditional theory teaching mode and task-driven teaching mode as well as project-guided teaching mode. It is a teaching mode that combines student characteristics and related professional training objectives. It is a kind of inquiry teaching mode. A new method based on constructivist teaching theory. The overall setting of the course is to set up guiding projects on the basis of investigations, mainly to solve the objectives of the knowledge system and to cultivate the spirit of teamwork, which is part of the construction of professional goals. In order to better promote student self-development projects, it is important to divide the project into a number of knowledge points. In the form of tasks, students can grasp the knowledge part of the project and guide the students' self-learning methods and processes. In addition, in order to ensure that the tasks can be carried out smoothly and that the tasks are not in the form due to the weak foundation of the students, the traditional knowledge should be used to help students increase their knowledge. The implementation of the project-guided task-driven teaching model can improve students' innovative awareness and entrepreneurial ability, and cultivate students' practical ability. It is an effective teaching method for training high-quality applied talents.

\section{Reform of Experimental Teaching Model}

Experiments are an important part of the teaching process. Therefore, great efforts must be made to deepen the reform of experimental teaching contents, experimental methods and experimental methods. The detection technology course has long focused on theoretical teaching while ignoring practice. How to combine theory with practice to fully reflect the technicality and practicality of the course is an urgent issue to be studied. For this reason, in the experimental teaching of the course, we put forward the principles of heavy skill training, ability training, and heavy engineering application. We try to use open experimental teaching and strengthen the experiment and practice link to improve students' comprehensive practical ability and innovation. ability. Focusing on the training requirement of innovation consciousness and entrepreneurial ability, teachers adopt open-ended experimental teaching, arrange less-validation-type experiments, and set up application-type, design-type, or comprehensive-type experiments, focusing on cultivating students' divergent thinking, logical thinking, and innovative thinking, and improving their Comprehensive practical ability. The experimental content of open experimental teaching is selected by the students themselves. After reading and understanding the experiment instruction book, students apply to the laboratory to instruct the teacher to interview and determine whether or not they can enter the experiment according to the student's preparation. This will help foster students' self-learning ability and hands-on ability. Students will change from passive acceptance to active participation, highlighting their dominant position in learning, inspiring students' interest in learning, and cultivating their creative thinking. It lays the foundation for certain applied talents with practical engineering capabilities and innovative spirit.

\section{E. Actively Guide Students to Participate in Various Types of Disciplines at all Levels and College Students Innovative and Entrepreneurial Projects}

Actively encourage students to participate in academic competitions and technological innovations in teaching. In combination with the actual situation of our school, encourage students to participate in college science and technology teams, combine theoretical knowledge with the cultivation of innovation and entrepreneurship, and encourage qualified students to participate in product development and technological transformation of out-of-school units. . At the same time, teachers also created conditions for students to participate in teachers' research projects. Through the training of literature review, data collection, research and analysis, program design, experimental research, data processing, report writing, and final answer, students not only cultivated their hands-on ability, but also cultivated a spirit of solidarity and collaboration; they broadened their horizons and enhanced Innovation consciousness and entrepreneurial ability have cultivated the necessary independent work ability and rigorous work style for research, laying a solid foundation for future work. Our students have achieved outstanding results in the College Students Innovation and Entrepreneurship Project, the National Undergraduate Electronic Design Competition, the Freescale Cup National Smart Car Contest, and the Internet+, which has greatly cultivated the students' scientific research and innovation spirit. Entrepreneurial ability.

\section{SUMMARY}

Detection technology is the core curriculum of automation, electrical information and other professional courses. Through the curriculum reform, students are proficient in the knowledge of detection technology and can be skillfully applied to practical projects, combined with specific engineering practice projects. Improving students' application ability and practical ability, and improving students' innovative spirit and entrepreneurial ability are of great significance in promoting the technological progress of enterprises and the upgrading of traditional industrial technologies. Through reforms, it is in line with the State's requirements for innovation and entrepreneurship education reform and personnel training in institutions of higher learning, adapting to market needs and social survival, and deepening reforms in innovation and entrepreneurship education in colleges and universities. In line with the school's basic theory of cultivation, innovation, and entrepreneurial ability, the goal of training high-quality applied talents with an international perspective and the development goal of "a well-known regional innovation and entrepreneurship university with a distinctive characteristics" will promote higher graduates Quality entrepreneurship and employment provide important support. 


\section{REFERENCES}

[1] Liu Yang. Discussion on the Reform of Innovation and Entrepreneurship Curriculum in Universities under the Background of "Double Creation" [J]. Journal of Ezhou University, 2017(2):76-78.

[2] Fang Yuefeng, Wang Xiaoyong, Yan Lifeng, et al. Computer professional practice teaching reform based on the cultivation of innovation and entrepreneurship ability $[\mathrm{J}]$. Computer Education, 2011(9):1-8.

[3] Lv Herong, Sun Fengqin. Innovation and Entrepreneurship-oriented Reform and Practice of Higher Vocational Training Curriculum[J].
Education and Occupation, 2014(14):156-157.

[4] Meng Xiangfei, Xie Qi, Li Xin. Practical Exploration of Teaching Reform of Sensor Principle and Detection Technology[J]. High Education Review, 2016(17):78-78.

[5] Guo Zeng, Luo Shaoyun. Research on the Course Reform of "Engineering Inspection Technology" Guided by Task-driven Model [J]. Journal of Zhangjiakou Vocational and Technical College, 2017(3).

[6] Liu Junjie, Xie Chunli, Wang Juan. Discussion on the Teaching Reform of Sensor and Detection Technology Course [J]. Quality Education in the West, 2017, 3(4): 85-85. 